DOI: $10.4274 /$ tpa.45.75

\title{
Çocukluk çağında bronşiyolitler: Etiopatojenez ve immünolojik akciğer hasarındaki yenilikler
}

\section{Bronchiolitis in childhood: Updates on etiopathogenesis and immunologic lung injury}

\author{
Hasan Yüksel, Ahmet Türkeli, Özge Yılmaz, Serhat Güler \\ Celal Bayar Üniversitesi Tıp Fakültesi, Pediatrik Alerii Bilim Dalı ve Solunum Birimi, Manisa, Türkiye
}

\section{Özet}

Akut bronșiyolit, iki yașından küçük çocuklarda sıklıkla viral etkenlerin neden olduğu bronșiyollerin enflamasyonu ile belirgin, hıșıltı 'wheezing', öksürük, hızlı solunum, göğüste çekilmeler ve ekspiryumda uzama ile seyreden bir hastalıktır. Etiolojide en sık etken respiratuar sinsisyal virüs olmakla birlikte birçok patojen rol almaktadır. Respiratuar sinsisyal virüs ya da diğer virüslerle karşılaşan tüm çocuklarda alt solunum yolu enfeksiyonu gelișmemesinde, viral patojenin oluşturduğu hücresel hasar ile birlikte konağa ait anatomik ve immünolojik etmenler rol oynamaktadır. Çocuklardaki viral enfeksiyonlar Th1/Th2 immün yanıtı değiştirebilmektedir. Hastalığın şiddeti immün yanıta bağlı olarak gelișen enflamasyonun derecesine göre değișebilmektedir. Ayrıca akciğerlerdeki non-adrenerjik non-kolinerjik nörojenik sistemin aktivasyonuna bağıı olarak hastalığın şiddetinde artma gözlenebilmektedir. Genetik yatkınlığı olan çocuklarda şiddetli respiratuar virüs enfeksiyonu gelişmektedir. Bu derlemede bronşiyolitin ortaya çıkmasında, şiddetli seyretmesinde sorumlu enfeksiyon ajanları yanında çevresel etmenler, konağın genetik ve yapısal yatkınlığı ve bu yatkınlıkta immün yanıtın rolü anlatılmıştır. (Türk Ped Arş 2010; 45: 75-81)

Anahtar sözcükler: Bronşiyolit, çocuk, immünopatojenez, respiratuar virüs

\section{Summary}

Acute bronchiolitis is a disease characterized with bronchiolar inflammation due to viral infections in children younger than two years that is associated with wheezing, cough, tachypnea, retractions and prolonged expiration. Many pathogens, among which respiratory syncytial virus is the most common, play role in the etiology. Cellular damage due to viral pathogens and anatomic and immunological factors of the host play a role in the development of lower respiratory tract infections only in some children exposed to respiratory syncytial virus and other viruses. Viral infections in children may change Th1/Th2 immune response pattern. Severity of disease changes with the degree of inflammation due to the immune response. Moreover, an increase in disease severity may be observed due to the activation of the nonadrenergic non-cholinergic neurogenic system. Severe RSV infections may develop in children with genetic predisposition. We explained the role of environmental factors, genetic and structural susceptibility of the host, and contribution of immunologic response in this susceptibility, in addition to the role of responsible infectious agents, in the development and severe progression of bronchiolitis (Turk Arch Ped 2010; 45: 75-81)

Key words: Bronchiolitis, child, immunopathogenesis, respiratory syncytial virus

\section{Giriş}

Akut bronşiyolit, iki yaşından küçük çocuklarda sıklıkla viral etkenlerin neden olduğu bronşiyollerin enflamasyonuyla belirgin hışıltı 'wheezing', öksürük, hızlı solunum, göğüste çekilmeler ve ekspiryumda uzama ile seyreden bir hastalıktır (1). Sık görülmesi, tekrarlayan tablolarının astım ile olası ilişkisi, süt çocukluğunda ciddi hastalık ve ölüm nedeni oluşturması hastalığın önemini arttırmaktadır (2).
Ancak enfeksiyon etkenleriyle karşılaşan çocukların tamamında alt solunum yolu enfeksiyonu gelişmemektedir. Enfeksiyona yatkınlık ve bronşiyolitin klinik olarak şiddetli seyretmesinde konağın havayolundaki immünolojik, yapısal ve işlevsel özellikleri önem taşımaktadır (3). Patojenlerin bronş alanına ulaşmalarından sonra birincil hedefleri olan epitel hücrelerinde oluşan enflamasyona (virüsün virülansı, immünolojik yanıt) bağlı olarak bronşiyolitin klinik tablodaki ağırlığı değişkenlik göstermektedir (4). Bunların yanında

Yazışma Adresi/Address for Correspondence: Dr. Hasan Yüksel, Celal Bayar Üniversitesi Tıp Fakültesi, Pediatrik Alerji Bilim Dalı ve Solunum Birimi, 45020, Manisa, Türkiye E-posta: hyukselefe@hotmail.com Geliş Tarihi/Received: 15.03.2010 Kabul Tarihi/Accepted: 29.03.2010 
bronşiyol çapının yaşıtlarına göre küçük olması ve akciğer işlevlerindeki azalma gibi farklılıklar klinik tablonun ağırlığını etkilemektedir (3). Hastalığı iki yaşına kadar çocukların tamamına yakınının geçirmesi, bir yaşın altında hastaneye yatışın en büyük nedeni oluşu ve astım ile ilişkisinin önem taşıması, yeni tedavi yöntemlerinin geliştirilmesini; bunun sağlanabilmesi de hastalık etiopatojenez ve immünolojisinin çok iyi anlaşımasını gerekli kılmaktadır.

\section{Etioloji}

Etiolojide en sık etken virüslerdir ve respiratuvar sinsisyal virüs (RSV) sıklık sıralamasında başta yer almaktadır. Ancak, rinovirüs, parainflüenza, inflüenza, adenovirüs, human metapneumovirus, enterovirüs ve human bocavirus de hastalığa neden olmaktadır. Hatta bilinen ve tespit edilebilen etken yelpazesi arttıkça RSV'nin göreceli yüksekliği azalmaktadır (5). Mycoplasma, chlamydia, ureaplasma, ve pneumocystis türleri de nadiren bronşiyolit ve bronşiyolit benzeri tabloya yol açan etkenlerdir (2,6-9). Olguların $1 / 5$ 'inde ise birden çok (ko-enfeksiyon) virüs görülür ve bu durumda klinik genellikle daha şiddetlidir (10).

\section{Respiratuar sinsisyal virüs}

Respiratuar sinsisyal virüs, Paramyxoviridae ailesi Pneumovirüs grubundan zarflı ve orta büyüklükte (120-300 $\mathrm{nm}$ ) bir solunum yolu virüsüdür. Tek ve negatif zincirli, segmente olmayan bir RNA'sı vardır. Respiratuar sinsisyal virüs proteinlerinin sekiz tanesi, enfekte hücrelerde ve viriyonlarda bulunan yapısal proteinlerdir. Yapısal olmayan NS1 ve NS2 proteinleri, viriyonlarda değil yalnızca enfekte hücrelerde bulunurlar $(6,11,12)$. Respiratuar sinsisyal virüsünün zarf yüzeyindeki iki önemli antijeni olan füzyon $(F)$ ve bağlanma (attachment;G) glikoproteinleri immünojen özellik taşır. Respiratuar sinsisyal virüsünün $A$ ve $B$ olmak üzere iki alt tipi vardır; bunlar özellikle $G$ protein yapısındaki değişikliklerden kaynaklanır (11). A gurubu RSV enfeksiyonları B gurubuna göre daha şiddetli seyretmektedir (13).

\section{Epidemiyoloji}

Akut bronşiyolit tüm dünyada yaygın olarak görülür. Respiratuar sinsisyal virüs enfeksiyonları ılık iklimlerde geç sonbaharda başlar ve ilkbahar ortalarına kadar devam eder $(6,7,14)$. Parainfluenza ve rinovirüs enfeksiyonları sonbahar ve ilkbahar aylarında bronşiyolit nedenidir $(2,14)$. Rinovirüsler atopik bireylerde ve daha büyük çocuklarda enfeksiyon yapar $(14,15)$. Human metepneumovirus, RSV ile aynı dönemlerde ve daha hafif şiddette enfeksiyon yapar (8). Mikoplazmalar ise genelde okul çağındaki çocuklarda akut bronşiyolit etkenidir (16).

Akut bronşiyolit ve RSV enfeksiyonu erkek çocuklarında daha fazla görülmektedir $(2,17)$. Erkek çocuklarında solunum yollarının çapının akciğer hacmine oranının kızlara göre daha küçük olması hastalığın erkek çocuklarda daha sık görülme nedenini açıklayabilmektedir (2).
Respiratuar sinsisyal virüs, bir yaşına kadar olan çocukların yaklaşık üçte ikisini enfekte eder ve bir yaşın altında alt solunum yolu enfeksiyonu nedeniyle hastane yatışlarının en büyük nedenidir (18). Çocukların tamamına yakını iki yașına geldiklerinde en az bir kez RSV ile enfekte olmuşlardır $(6,19)$. Respiratuar sinsisyal virüs enfeksiyonlu çocukların yaklaşık \%20-30'unda bronşiyolit tablosu oluşmakta ve \%3 kadarı da bir yaş altında hastaneye yatmaktadır. Respiratuar sinsisyal virüs nedeniyle hastaneye yatan çocuklarda ölüm oranı yaklaşık olarak \%2-3 kadar yüksek olabilmektedir (18). Bazı risk etmeni taşıyan çocuklarda daha ciddi klinik tablo ve daha yüksek ölüm oranı görülebilmektedir. Doğuştan kalp hastalı̆̆ı (özellikle pulmoner hipertansiyonla beraber soldan sağa şantı olanlar), bronkopulmoner displazi, reaktif havayolu hastalığı, kistik fibroz, doğuştan ya da kazanılımış immün yetersizlik risk etmenleri arasında yer alır. Erken doğmuş ve küçük bebekler, kordon kanında interferon-gama (IFN- $\gamma$ ) düzeyi düşük bulunanlar, sindirim sistemi hastalığı (malnütrisyon dahil) olanlar, kemik iliği ve organ nakli yapılanlar ve evde oksijen tedavisi alan hastalar riskli hasta grubunu oluşturmaktadır $(2,20,21)$.

Erken doğmuş bebekler (özellikle 32 haftanın altında) ve küçük bebekler (üç ay altında) transplasental geçen antikorların azlığına bağlı olarak viral enfeksiyonlara yatkınlık gösterirler. Düşük doğum ağırlıkı bebeklerde ve küçük çocuklarda solunum sistemi ya da immün sistemin göreceli olarak olgunlaşmamış olması nedeniyle de enfeksiyonlara yatkınlık gözlenmektedir $(17,22)$.

Ayrıca yaştan ve kişiden bağımsız genel risk etmenlerinden sosyoekonomik durum, anne beslenmesi, genel sağlık durumu ya da stres, fetüsün akciğer gelişimini değiştirerek RSV bronşiyolitinin şiddetini ve oluşma riskini etkileyebilir (23). Kalabalık yaşam koşullarında örneğin okul çağında kardeşi olan, başka bir nedenle hastanede yatan, şehirde yaşayan veya kreşlerde bulunan süt çocuklarında bronşiyolit riski yüksektir $(17,21)$. Pasif sigara içiciliği, annenin hamilelikte ya da sonrasında sigara içmesi çocuğun akciğer olgunlaşmasını daha sonra da akciğer işlevlerini olumsuz yönde etkilemekte ve daha şidddetli enfeksiyon geçirmeye neden olmaktadır $(2,17,23)$.

\section{Patojenez}

Respiratuar sinsisyal virüs ya da diğer virüslerle karşılaşan çocukların tümünde alt solunum yolu enfeksiyonu gelişmemektedir. Burada viral patojenin oluşturduğu hücresel hasar ile konağa ait anatomik ve immünolojik etmenler önemli rol oynamaktadır $(2,6)$. Havayolları dar ve solunum işlevleri bozuk olan çocuklarda hastalık daha kolay gelişmekte ve daha ciddi tablo oluşmaktadır $(2,23)$. Bronşiyolitin ilk 18-24 saatinde küçük havayollarındaki viral çoğalma enflamasyona ve bronşiyal epitelde nekroza yol açar. Siliyalar bozuk olduğu için salgıların alt solunum yollarından yukarıya doğru iletilmesi bozulur. Ayrıca, mukus üretiminde ortaya çıkan artış nedeni ile lümen içindeki salgılar çoğalır 
ve submukoza ödemli bir hal alır. Sonuç olarak hava yolundaki salgı, ödem ve nekrotik oluşum alt solunum yollarında tıkanmaya, hava yollarında daralmaya ve tıkanmaya neden olur. Bu tıkanmalar, genellikle "check-valf" mekanizması sonucu akciğerlerde așıı havalanmaya yol açar. Bununla birlikte yer yer atelektazik alanlar da oluşabilir $(2,6)$. Süt çocuklarının periferik havayolu direnci, erişkinlere oranla daha fazla olduğu için çok küçük enflamatuar değişiklikler bile bronşiyollerde ciddi daralmaya ve bunun sonucunda hışıltıya neden olabilmektedir. Çocuklarda Kohn deliklerinin sayısı az olduğu için etkin kollateral ventilasyon yapılamaz. Tüm bu süreç normal gaz alışverişini bozarak erken dönemde hipoksemiye ve ağır olgularda da bir süre sonra hiperkapniye yol açmaktadır (24).

Akut bronşiyolite genetik ve yapısal yatkınlık

Thomsen ve ark.'ları (25) yakın dönemde yapmıs oldukları çalıșmada, tek yumurta ikizlerinde çift yumurta ikizlerine göre şiddetli RSV enfeksiyonunun artmış olduğunu göstermişlerdir. Şiddetli RSV enfeksiyonu gelişmesine eğilimdeki genetik katkının yaklaşık \%20 olduğu tahmin edilmektedir. Doğal ve edinsel immün sistem öğelerine ait çeşitli tek gen nükleotid polimorfizmi (SNP) ile RSV kaynaklı hastaneye yatışlar arasında anlamlı ilişki dikkati çekmektedir $(18,25)$. Bazı interlökin (IL), kemokin ve almaçlarına (reseptörlerine) ait gen polimorfizmlerinin şiddetli RSV enfeksiyonuyla birlikteliği gösterilmiștir (26). Yüksek riskli, bulguları olan RSV'li hastalarda "Toll-like" almaç-4 (TLR4) ile ilişkili SNP hetorozigositesi saptanmıştır (27). Sürfaktan proteinlerinin (SP) polimorfizmi ile şiddetli RSV enfeksiyonu birlikteliği gösterilmiştir. Şiddetli RSV enfeksiyonunda, RSV'li çocukların burun salgıları ve epitel hücrelerinde "Regulated on Activation Normal T Cell Expressed and Secreted" (RANTES) gibi kemokinlerin aktiviteleri artmıștır. RANTES promoter gen polimorfizminde RSV'ye bağlı hastaneye yatışlar kontrol grubuna göre daha fazla bulunmuştur (28).

Akut bronşiyolitte immün yanıt ve doku hasarı ilișkisi

Respiratuar sinsisyal virüs enfeksiyonunun immünolojisi ve immünopatojenezi karmaşıktır. İmmün sistemin hücresel ve hümoral bileşenlerinin hem patojenez hem de korunmada etkisi olduğu bilinmesine rağmen, patojenez tam olarak aydınlanmamıştır (6).

Solunum yolu epitel hücreleri solunum yolu enfeksiyonlarının birincil hedefidir. Epitel hücreleri aynı zamanda virüslere karșı doğal immün yanıtta alveoler makrofajlar ve dentritik hücreler $(\mathrm{DH})$ gibi profesyonel antijen sunan hücrelerden önce ilk savunmayı oluştururlar (29). Virüsler doğrudan enfeksiyona bağlı olarak havayolu epitel hücresi nekrozu ya da dolaylı olarak havayolu ve akciğerlerde üretilen proenflamatuar yanit ile havayolunda hasar yapabilirler. Respiratuar sinsisyal virüs bronșiyolitinde enfekte epitel hücrelerinde NF-кB (nükleer faktör kappa B) yolağı aktive olarak enflamatuar kemokinler ve sitokinler, düşük moleküllü araçlar [lökotrienler (LT), nitrik oksit (NO), prostaglandin], tümör nekrotizan faktör alfa (TNF- $\alpha$ ) sentezlenir. Bunu izleyerek nötrofiller, makrofajlar, DH ve lenfosit subgrubları havayoluna toplanırlar $(30,31)$. Enflamatuar sitokin- ler ve patojen tanıyan almaç (PRR) molekülleri edinsel immün yanıın uyarıması için gerekli olan $\mathrm{DH}$ olgunlaşmasını ve trafiğini başlatıllar $(30,31)$. Çocuklarda doğal RSV enfeksiyonuna karşı antikor yanıtı erişkinlere göre daha azdır fakat erișkinlerde de RSV'ye karșı antikor yanıtı diğer patojenlerle karșılaștırıldığında daha zayıf olmaktadır. RSV birincil enfeksiyonu kalıcı immünite bırakmaz. Tekrar eden enfeksiyonlar genellikle daha hafif seyretmektedir (6).

İmmün yanıt ve virüs ilişkili hastalık ağırı̆̆ının artması

Respiratuar sinsisyal virüs bronşiyolitinin şiddetli formları akciğerlerdeki viral çoğalmanın büyüklüğünden daha çok aşırı immün yanıta bağlı olarak ortaya çıkar. Bu konuda bilgilerimiz 1960'larda inaktive formalin RSV aşıSı uygulamasındaki deneyimlere dayanmaktadır. Formalinle inaktive edilmiş RSV aşıSı olan çocuklarda virüsle karşılaştıktan sonra ağır RSV hastalığı görülmüș ve aşılanmış çocukların akciğerlerindeki yoğun enflamatuar enfiltrasyon, ağır hastalığın immünopatolojik bir nedeni olabileceğini düşündürmüştür. Sıçanların, çocukları aşılamak için kullanılan formalin ile inaktive edilmiş RSV aşısıyla aşılandığı çalışmada, daha çok nötrofillerden oluşan alveolit ve daha çok lenfositlerden oluşan peribronşiyolit gibi ağır hastalığın histolojik bulgularının aynı miktardaki formalin ile inaktive edilmiş aşı ile aşılanan ve ölümle sonlanan iki çocuktaki bulgularla uyumlu olduğu gösterilmiştir. Bu bulgu, immünopatolojik olarak ağır hastalığın bir histolojik göstergesi olan alveolitin önemini vurgulamıştır (6).

Çocuklardaki viral enfeksiyonlar Th1/Th2 immün yanıtın şeklini değiştirebilmektedir. Respiratuar sinsisyal virüs içeren viral enfeksiyonların kontrolünde immün farklıaşmanın Th1 yönünde olmasının önemi çok sayıda fare ve insan çalışmasında gösterilmiştir (32).

"Toll like" almaçlar: Birçok patojene karșı doğal immün yanıtın oluşmasını sağlayan bir grup tip 1 transmembran proteinidir. Doğal immün sistem patojenlerde ortak olan bir dizi moleküler yapıyı tanıyabilmekte ve böylece konağa ait olan ve olmayanı belirleyerek savunmayı bașlatabilmektedir. Patojenler üzerinde bu evrimsel olarak korunmuş moleküler yapılara hastalık etkenlerine eşlik eden moleküler yapılar (PAMP), doğal immün sistem hücreleri üzerinde bunları tanıyan almaçlara da PRR denilmektedir (33). Havayolu epitel hücreleri normalde çok düșük düzeylerde TLR4 sunarlar, fakat RSV enfeksiyonu TLR4 sunumunu ve membran yerleșimini arttırmaktadır (34). RSV-F proteini insan monositlerindeki TLR4 ve CD14 ile etkileşim göstererek sitoplazma içindeki Toll/IL1 almaç aracllığı ile NF-kB yolağını aktive eder. Bunu izleyerek antimikrobiyal protein ve enflamatuar sitokinler sentezlenir $(18,35)$.

"Toll like" almaç 4 tek gen nükleotid polimorfizminin (SNP) ișlevsel anlamı araştırılmaktadır. Asp299Gly ve Thr399lle aleli mutasyonunun şiddetli RSV bronşiyoliti ile birlikteliği gösterilmiştir (36). Tulic ve ark.'larının (37) insan bronșiyal epitel hücrelerindeki çalıșmasında Asp299Gly ve Thr399lle alleli SNP'de TLR4 etkinliği bozulmaktadır. Bu azalmış NF-kB sinyali ve proenflamatuar sitokin yanııına neden olmaktadır. Aynı zamanda, çocukların periferik kan 
mononükleer hücrelerinde beliren TLR4 çeşitlerinin RSV'ye yanıtının körleşmiş olduğu gösterilmiştir. Bu veriler, RSV'nin TLR4 yolağı aracılığıyla hava yolunu viral enefeksiyonlara duyarlı hale getirdiğini göstermektedir (31). Bununla birlikte bronşiyolit patojenezinde TLR'in rolü hala açıklama gerektirmektedir. "Toll like" almaç 4 ve diğer TLR gen ekspresyonlarındaki mutasyon ve varyasyonlar bronşiyolitli çocuklardaki klinik durumların çeşitliliğini açıklayabilir.

Bronşiyolit patojenezi ve immün yanıt ile ilgili sürfaktan proteinleri: Sürfaktan proteinler doğal immün sisteme ait olan PRR olarak işlev görürler. İmmün sistemin patojenle ilk etkileşime geçerek tanımlayan öğeleri oldukları düşünülmektedir. SP-A ve SP-D özgün olarak RSV-F ve RSV-G proteinlerine bağlanırlar ve RSV'yi makrofajlar için opsonize ederlerler (38). Ayrıca makrofajları doğrudan da uyarabilirler. Kemotaksisi ve fagositozu arttırırlar, sitokin salınımını düzenlerler (29). Makrofajlardaki SP-A aracılıklı etki, NF-кB yolağı aktivasyonu ve sitokin salgılanmasının artışını içeren TLR4 kompleksi aracılığıyla gerçekleşmektedir. Bunun yanında SP-A, RSV-F proteinine bağlanarak virüsün hedef hücreye girmesini ve sinsisyum oluşumunu engelleyerek virüsün etkin nötralizasyonunu sağlar (38).

Şiddetli RSV enfeksiyonu geçirme eğilimi olan çocuklarda SP-A ve SP-D gen polimormizmi ilişkisi gösterilmiştir $(36,37)$. SP-A ve SP-D düzeyi RSV'li hastalarda konrol gurubu hastalara göre daha düşük düzeyde bulunmuştur. RSV'li ventile hastalardan alınan bronkoalveoler yıkama sıvısında SP-A, B ve D düzeylerinin düşük olduğu gösterilmiştir (35). Bu şiddetli enfeksiyon akciğerlerde viral persistansın uzamasına bağlıdır ve sürfaktan proteinler ile viral klirensin ilişkili olduğunu göstermektedir $(34,39)$.

Sitokinler ve kemokinler: Sitokinler, özgül almaçlara bağlanarak hedef hücrede gen ekspresyonunu değiştiren sinyal transdüksiyon yollarını tetikleyen düşük molekül ağırlıklı glikoproteinlerdir. Doğal RSV ile enfekte havayolu epitel hücreleri ve immün sistem hücreleri NF-кB yolağının aktivasyonuyla proenflamatuar ve antienflamatuar birçok sitokini (IL-6, IL-8, TNF- $\alpha$, IL-1 $\alpha$, IFN- $\beta$, IFN- $\gamma$, IL-11 vb.) üretirler $(30,31)$. Kemokinler, lökositlerin hareketlerini ve kandan dokulara geçişini düzenleyen ve sitokinlere yapısal olarak benzerlik gösteren geniş bir ailedir. Enflamatuar uyarıya yanıt olarak çeşitli hücrelerden salınır ve lökositleri enflamasyon bölgesine toplarlar (31). Kemokinlerin salınımı başlangıçta nötrofilik enflamasyon gösterirken CD4+T hücre ve eozinofil kemotaksisi muhtemelen IL-4, IL-5 ve IL-13 salınımına bağlıdır. Fakat bu etkiler virüsün tamamı ya da $F$ proteini aracılığıyla olurken RSV-G ve/veya SH proteinleri erken dönemde kemokin salınımını engellerler (29). Respiratuar sinsisyal virüs enfeksiyonlu çocuklarda yapılan çalışmalar, IL-8, monosit kemoatraktan protein-1 (MCP-1), TNF- $\alpha$, eotaksin, makrofaj enflamatuar protein-1 alfa (MIP-1 $\alpha$ /CCL3) ve RANTES/CCL5 düzeylerinin bronşiyolitli çocukların solunum yolu salgılarında enfekte olmayan kontrol gurubuyla karşılaştırıldığında artmış olduğunu göstermiştir (40). MIP-1 $\alpha$, RSV enfeksiyonuna enflamatuar yanıtın başlamasında önemli bir proteindir. Solunum salgıla- rındaki MIP-1 $\alpha$ miktarı hipoksik şekilli bronşiyolitlerde hipoksik olmayan bronşiyolit veya tek başına üst solunum yolu enfeksiyonuna göre daha fazladır ve bireylerde ölçülen düşük oksijen yoğunluğu ile uyumludur. Bu sonuçlar, salınan MIP-1 $\alpha$ miktarı ve almaç duyarlılığının hipoksi derecesine katkıda bulunduğunu göstermektedir (41).

MIP-1 $\alpha$ ve RANTES, CCR5 almacına bağlanarak etki gösterirler ve çocuklarda CCR5 almacının polimorfizmlerinin şiddetli RSV enfeksiyonuyla birlikteliği gösterilmiştir (42).

İnterlökin (IL)-18, IFN- $\gamma$ üretimini artırır ve IgE üretimini engeller. IL-18 polimorfizmi ile artmış serum IgE düzeyleri, atopi, astım ve şiddetli RSV enfeksiyonu birlikteliği gösterilmiştir (43).

Güçlü bir kemoatraktan olan CXCL8 (IL-8)'in RSV ile enfekte bronşiyal epitel hücrelerinde transkripsiyonunun arttığı gösterilmiştir. Hull ve ark.' ları (44) artmış CXCL8 düzeyi ile ilişkili ve daha şiddetli RSV enfeksiyonlarında, CXCL8 polimorfizmi saptamışlardır.

Nötrofil, monosit ve $\mathrm{T}$ hücrelerden salgılanan "interferon-y-inducible" protein-10 (IP-10/CXCL1O ) şiddetli RSV enfeksiyonlarında havayollarında artmıştır. IP-10 apopitotik nötrofillerin fagositozuna yardım için monositleri akciğere toplar. McNamara ve ark.'ları (45), CXCL10 eksikliğinde apopitotik nötrofillerin ortamdan kaldırılamaması sonucunda içeriklerinin dokulara yayılarak doku hasarını arttıracaklarını göstermişlerdir.

RSV-G protein, lökositlerin "eksprese" ettiği kemokin almacı $\left(\mathrm{CX}_{3} \mathrm{CR} 1\right)$ ile bağlanarak etki eden $\mathrm{CX}{ }_{3} \mathrm{CL} 1$ kemokinine (fractalkine) benzer yapıdadır. Muhtemelen lökositler üzerindeki $\mathrm{CX}_{3} \mathrm{CR} 1$ için fractalkine ile yanmaya girip fractalkine aracılıklı immün yanıtı değiştirerek viral çoğalmasını ve yaşamını devem ettirir (29). Respiratuar sinsisyal virüs bronşiyolitli çocuklardan alınan örneklerde konvelasan fazda (postinfeksiyöz 6-8 hafta) kontrol guruplarına göre CD8 T hücrelerde anlamlı derecede düşük $\mathrm{CX}_{3} \mathrm{CR} 1$ saptanmıştır. $\mathrm{CX}_{3} \mathrm{CR} 1$ düzeyleri sitotoksik $T$ hücre işlev etkinliğini yansıttığı için onların düşük düzeyi "konvelasan" dönemde bozulmuş immün yanıtı göstermektedir. Bu da RSV enfeksiyonu ya da enflamasyonun devam ettiğini düşündürmektedir (46). Amanatidou ve ark.'ları, $\mathrm{CX}_{3} \mathrm{CR} 1$ Thr280Met SNP'de şiddetli RSV bronşiyolit riskinin artmış olduğunu göstermişlerdir. Bu mutasyon, hem virüslerin girişini kolaylaştırarak, hem de viral klirens etkinliğini azaltarak uygunsuz uyarı ve immünopatojenik immün yanıta neden olmaktadır (47).

Düşük molekül ağırıklı araçlar: Lökotrienler, prostoglandinler ve NO, aktive enflamatuar hücrelerden salınan düşük molekül ağırlıklı araçlardır. Sisteinil lökotrienler (LTC4, LTD4, LTE4) ve LTB4 RSV enfeksiyonlu çocuklarda ve fare örneklerinde defalarca nazofaringeal ve trakeobronşiyal salgılarda saptanmışlardır (48). Fare ile yapılan deneysel RSV enfeksiyonunda sisteinil LT'ler havayolunda en yüksek düzeye hastalığın en şiddetli olduğu anda ulaşmaktadırlar (49). Bu çalışmalar, LT'nin RSV enfeksiyonu sırasında birincil olarak enflamatuar hücrelerden salındığını göstermektedir. Ayrıca, bronşiyolitli çocuklarda LT miktarı wheezingi olmayan üst solunum yolu enfeksiyonlu çocuklara göre daha fazladır. Lökotrienlere ek olarak prostoglandin metabolitleri de araşidonik asit metabolizmasının aktive olmasına bağlı olarak 
RSV enfeksiyonu sırasında ve sonrasında plazmada artmaktadır (48). Pulmoner epitel hücrelerince salınan NO, RSV enfeksiyonunda ilk doğal immün yanıtı oluşturur ve RSV yoğunluğuyla NO üretimi ters ilişki gösterir (29). Fakat RSV bronşiyolitli çocuklara solunum yolundan geçerek NO uygulanması havayolu direncini azaltmamaktadır. Bundan dolayı RSV enfeksiyonunda solübl enflamatuar araçlar düz kas kasılmasını etkilemeyebilirler (50).

Akut bronşiyolitte bronşiyal non adrenerjik non

\section{kolinerjik nörojenik sistem}

Solunum sisteminde nonadrenerjik nonkolinerjik (NANK) sistem, eksitatör (NANKe) ve inhibitör (NANKi) bileşenler ile dinamik bir denge içindedir. Bronkokonstriktif etki yapan NANK'e yanıtlar, enflamasyonu uyaran tașikininler substans $P$ ve nörokinin A (NKA) aracılığıyla olmaktadır. Bronkorelaksasyon ve antienflamatuar etki yaratan NANKi yanıt ise vazoaktif intestinal peptit (VIP) ve NO nörotransmiterleri aracılığıyla olmaktadır. Miyelinize olmayan sensoriyel liflerden oluşan NANKe sistem, solunum yolu epiteli altında yoğun bir ağ oluşturmaktadır. Taşikininler, mononükleer hücre ve granülositleri de içeren çeşitli hedef hücrelerde bulunan 3G protein, NK1, NK2 ve NK3'ü etkilerler. NK1 almaç alt tipi substans P için özellikle yüksek tutunma özelliği gösterir ve onun aracıllğılla enflamatuar ve etki meydana gelir.

Nörotrofin ailesinin ilk keşfedilen öğesi olan nerve growth factor (NGF) bu nöronal sisteminin düzenlenmesinde anahtar bir rol oynamaktadır. Nörotrofinler periferal getirici (afferent) ve götürücü (efferent) nöronların yaşaması, farklılaşması ve apoptozunu etkiler ve özgül olarak substans $P$ ve diğer peptit nörotransmiterlerin öncüleri olan genlerin ekspresyonunu kontrol ederler. Nerve growth factor bu yüzden özgül dokuların innervasyonunu geliştirir. Nerve growth factor aynı zamanda çeşitli enflamatuar araçları salgılayan epitelyal ve enflamatuar hücreleri de içeren nöronal olmayan hücrelerce sentezlenmekte ve salınmaktadır. Nerve growth factor epitelyal hücrelerde ortaya çıktığında sensoriyel nöronlardan substans $P$ ve diğer taşikininlerin üretimini ve salınımını arttırır (31). Kaltreider ve ark.'Jarının (51) çalışmasında, substans P'nin pulmoner immün yanıt sırasında yerel olarak salgılandığı ve yüksek afiniteli substans $P$ almaçlarının (NK1) perivasküler, peribronşiyal ve alveoler enflamasyondaki granülositler ve mononükleer hücrelerde eksprese edildiği gösterilmiștir. Diğer gruplar çalışmalarında RSV enfeksiyonlu farelerin havayollarında hem subtans P'nin bağlanacağı alanda artma hem de NK1 almaçlarında artış göstermişlerdir. NANKe sisteminin aktivasyonu yanında RSV enfeksiyonlu sıçanlarda NANKi sistemin azaldığı da gösterilmiştir.

Solunum yolu epitel hücrelerinin RSV ile enfeksiyonunda NANK sistem ile igili olası sekeller şöyle gelişmektedir: Nerve growth factor salınımı substans $P$ üretimini uyarır ve çeșitli enfiltrasyon hücrelerinden substans $P$ almacı (NK1) ekspresyonunu arttırır. Substans P-NK1 almaç etkileşimi trakeobronşiyal dolaşımda vazodilatasyon yapar, postkapiler venüllerin geçirgenliği artar, havayolu mukozasında eksudatif ödem meydana gelir, lökositler vasküler endotele çekilir ve en önemlisi alveoler makrofajlar ve monositler aktive olarak TNF- $\alpha$ ve IL-6 gibi sitokinleri salgılarlar. Dahası bu ligand almaç etkileşimi sonucunda mast hücrelerinin degranulasyonu ile histamin, LT, prostoglandin ve sitokin gibi vazoaktif, nosiseptif ve proenflamatuar araçlar salgılanır. Yukarıda sözü geçen olayların tamamı henüz insanlarda gösterilememiştir (31).

\section{Respiratuar sinsisyal virüs ve antijen sunan hücre} etkileşimi

Makrofajlar, patojenleri diğer hücrelere sunarlar. Aynı zamanda yaygın enflamasyonu baskılayarak doğal ve edinsel immün sistemde immünsüpresör etki gösterirler. RSV-F proteini makrofajlara TLR4 aracılığıyla bağlandığı zaman TNF- $\alpha$, CXCL-6 (granulocyte chemotactic protein2/GCP-2) ve CXCL-12 gibi proenflamatuar araçların üretimiyle sonuçlanan NF-кB yolağı aktivasyonu olur. Respiratuar sinsisyal virüs enfeksiyonu aynı zamanda makrofajlardan TLR-3 ekspresyonunu arttırarak CCL-5 gibi kemokinlerin üretimine neden olurlar $(31,52)$.

Respiratuar sinsisyal virüs ve havayolu $\mathrm{DH}$ arasındaki ilişki hakkında çok az bilgi vardır. Respiratuar sinsisyal virüs ile enfekte DH'ler (insan kordon kanı) influenza ile enfekte DH ile karşılaştırıldığında yüksek miktarda IL-10, IL-11 ve prostoglandin E2 ve düşük düzeylerde proenflamatuar özellikli IL-12 salgılarlar (53). IL-11, NF-кB yolağı ve proenflamatuar sitokinlerin (TNF- $\alpha$ ve IL-12) salgılanmasını inhibe ederek in vivo ve in vitro güçlü antienflamatuar etkiye sahiptir (54). Bu bulgu, DH'nin bronşiyolit patojenezinde rol aldığını göstermektedir (53). Plazmositik dendritik hücreler (pDH) sistemik dolaşımda ve lenf dokularında bulunan DH'nin alt grubudurlar. Virüs ve bakterilerin uyarısıyla üretilen interferon alfa ve beta'nın (IFN- $\alpha$ ve IFN- $\beta$ ) ana kaynaklarıdırlar. pDC'in RSV ile enfeksiyonu konağın IFN üretimini engeller. pDC'in naif $T$ hücrelerini aktive etme kapasitesi düşer. T hücrelerinde düşük miktarda artma oluşur ve sonuçta azalmış sitokin üretimi ortaya çıkar (55). Diğer virüslerle karşılaştıııldığında RSV, IFN- $\alpha$ ve $\beta$ 'nın zayıf bir uyarıcısıdır ve bundan dolayı antiviral etkilere daha dirençlidir. Bu etkiler, RSV nin yapısal olmayan proteinleri olan NS1 ve NS2 aracılığıyla gerçekleşir ve antiviral IFN'nin bașlattığı yanıt yok edilir $(56,57)$.

Akut bronşiyolitte havayoluna immün hücre toplanması RSV enfeksiyonu sırasında havayolu yapısal hücrelerinden salınan kemokin ve sitokinler, lökositlerin dolaşımdan enfeksiyon bölgesine toplanmasına neden olurlar. Nötrofiller havayolunda 1-6. günlerde baskın olan hücrelerdir. Monositler pik değerlere 3-11. günlerde ulaşılar. Lenfositler en yüksek düzeye 11. gün civarı ulaşır. Doğal immün sistemin bu ilk yanıtını (nötrofiller, monositler ve doğal öldürücü hücreler) daha sonra edinsel immün sistem hücreleri ( $T$ ve B lenfositler) izler (31).

RSV ile karşılaşan monositlerde HLA-DR ve CD80-86 ve CD40 gibi ko-stimülatörlerin artışı gözlenir ve bunların antijen sunma kapasiteleri, hücre toplayıcı etkileri ve edinsel immün sistemi uyarıcı etkileri artar. IL-8 kemokini ve IL-6, TNF- $\alpha$, IL$1 \beta$, GM-CSF, IL-16 gibi proenflamatuar sitokinleri, IL-10 and $\mathrm{PGE}_{2}$ gibi antienflamatuar araçları üretirler $(31,58)$.

Doğal öldürücü hücreler, hücre ölüm yolağının aktivasyonunda önemli olan serin proteaz içeren granzimlere sahiptirler. Doğrudan hücre ölümüne neden olurlar. Respiratuar sinsisyal virüs bronşiyolitinin fare modelinde NK hücrelerin enfeksiyonun ilk üç gününde akciğer içine toplandığı gösterilmiştir. Doğal öldürücü hücrelerin akciğer içinde toplanma- 
sında, enfekte havayolu epitel hücrelerinin ürettiği MIP-1 $\alpha$ ve IFN- $\beta$ önem taşımaktadır. Bem ve ark.'ları (59), şiddetli RSV enfeksiyonu olan çocuklarda NK hücrelerin artmış granzim B ekspresyonuna sahip olduğunu göstermişlerdir. Doğal öldürücü hücreler IFN- $\gamma$ 'nın önemli bir kaynağıdır. IFN- $\gamma$ düzeyi akciğerlerde altıncı gün civarı pik yapar. IFN- $\gamma$, CD8 T hücrelerinin efektör sitotoksik $T$ hücrelerine farklılașmasına, sayıca artmasına ve RSV'ye karșı antiviral yanıtın artmasına neden olur (60). Respiratuar sinsisyal virüs immünopatojenezinde IFN- $\gamma$ 'nın koruyucu rolü gözönüne alındığında, anlamlı derecede düşük IFN- $\gamma$ ekspresyonu olan çocuklarda şiddetli RSV enfeksiyonu görülmesi beklenen bir durumdur (21). Ayrıca NK hücreler doğal ve edinsel immün sistem arasında düzenleyici rol oynarlar. Akciğerlerde de eozinofiliyi ve hastalığın şiddetini azaltırlar (61).

Respiratuar sinsisyal virüs bronşiyoliti sırasında havayolundaki baskın hücre grubu, enfeksiyon bölgesine ilk göç eden hücrelerin \%75'den fazlasını oluşturan nötrofillerdir. IL-8 ve RANTES, viral enfeksiyonlu havayolu epitel hücrelerinden salgılanan birincil nötrofil kemoatraktan molekülleridir (62).

Eozinofillerin RSV enfeksiyonunda solunum sisteminde degranülasyonu, eozinofil ribonükleaz, eozinofil derive nörotoksin ve eozinofil katyonik protein (ECP) salınımına neden olur. Respiratuar sinsisyal virüs enfeksiyonlu bireylerde ECP'de artış gösterilmiştir. Eozinofil ürünleri enfekte hücrelerin yok edilmesinde etkilidirler, ancak, eozinofil aracılıklı sitotoksisiteye bağlı olarak enfekte olmayan epitel hücrelerinde oluşan hasar şiddetli RSV hastalığının gelişiminde etkili olabilir.

Bazofil ve mast hücrelerinin rolü RSV immünopatojenezinde çok açık değildir. Klinik çalışmalar, bazofil ve mast hücrelerinden salgılanan histamin ve LTC4 konsantrasyonu akciğer salgılarında yüksek olan çocuklarda, RSV'ye bağlı alt solunum yolu enfeksiyonlarının daha fazla olduğunu göstermektedir. Mast hücre belirteci olan triptaz, akut bronşiyolitli çocukların solunum sisteminde saptanmıştır. Bu da viral enfeksiyonlar sırasında mast hücre ve bazofillerin havayolu içine doğru yayılarak erken degranüle olduğunu ve enflamatuar araçların salındığını göstermektedir (31).

\section{Sonuç}

Bronşiyolit özellikle erken çocukluk çağında viral solunum yolu enfeksiyonları sırası ve sonrasında sık görülen bir tablodur. Yinelemesi ve astım gelişimi ile ilişkisi olduğunun gösterilmesi nedeni ile patojenezinin aydınlatılması ve hastalık açısından risk grubunu oluşturan çocukların belirlenmesi önemlidir. Bronşiyolitin ortaya çıkmasında, şiddetli seyretmesinde ve astım ile ilișkisinde sorumlu enfeksiyon ajanları yanında konağın genetik ve yapısal yatkınlığının ve bu yatkınlıkta immün yanıtın rol oynadığı gösterilmiştir. Bu nedenle bronşiyolit, patojenez ve risk fetmenleri ile çevresel ve genetik yatkınlığın etkileştiği bir tablo sonucunda ortaya çıkmaktadır. Önümüzdeki yıllarda hastalığın görülmesini, ölüm oranını ve uzun süreli sekellerinin önlenmesini hedefleyecek yeni tedavi yöntemlerinin oluşturulmasında, bu yatkınlığın oluşturacağı akciğer hasar mekanizmalarının göz önünde tutulması gerekmektedir.

\section{Kaynaklar}

1. Türk Toraks Derneği Akut bronşiyolit tanı ve tedavi uzlaşı raporu. Türk Toraks Dergisi 2009; 10: Ek 1.

2. Cokuğraş H. Bronşiyolit tanı ve tedavisi. İçinde: Dağlı E, Karakoç F (yazarlar). Çocuk Göğüs Hastalıkları. İstanbul: Nobel Tıp Kitabevleri, 2007: 133-7.

3. Watts KD, Goodman DM. Wheezing in infants: Bronchiolitis. In: Nelson WE, Arvis AM, Kliegman RM (eds). Nelson Textbook of Pediatrics. Philadelphia: Saunders, 2007: 1773-8.

4. Miller AL, Bowlin TL, Lukacs NW. Respiratory syncytial virusinduced chemokine production: Linking viral replication to chemokine production in vitro and in vivo. J Infect Dis 2004 189: 1419-30. (Abstract) / (Full Text) / (PDF)

5. González de DJ, Sangrador CO. Consensus conference on acute bronchiolitis (II): epidemiology of acute bronchiolitis. An Pediatr 2010; 72: 222. (Abstract)

6. DiMango E, Prince A. Respiratory infection. In: Gershon A Hotez PJ, Katz SL (eds). Krugman's Infectious Diseases of Children. Philadelphia: Mosby, 2006: 493-530.

7. Yüksel H, Yilmaz O, Akçali S, et al. Common viral etiologies of community acquired lower respiratory tract infections in young children and their relationship with long term complications. Mikrobiyol Bul 2008; 42: 429-35. (Abstract) / (Full Text)

8. Semple MG, Cowell A, Dove W, et al. Dual infection of infants by human metapneumovirüs and human respiratory syncytiavirüs is strongly associated with severe bronchiolitis. J Infect Dis 2005; 191: 382-6. (Abstract) / (Full Text) / (PDF)

9. Miron D, Srugo I, Kra-Oz Z, et al. Sole pathogen in acute bronchiolitis: Is there a role for other organisms apart from respiratory syncytial virüs? Pediatr Infect Dis J 2010; 29: 7-10. (Abstract)

10. Legg JP, Warner JA, Johnston SL, Warner JO. Frequency of detection of picornaviruses and seven other respiratory pathogens in infants. Pediatr Infect Dis J 2005; 24: 611-6. (Abstract)

11. Hacımustafaoğlu M. RSV enfeksiyonları. ANKEM Derg 2006; 20 : 240-7. (PDF)

12. Wennergren G, Kristjansson S. Relationship between respiratory syncytial virus bronchiolitis and future obstructive airway diseases. Eur Respir J 2001; 18: 1044-58. (Abstract) / (Full Text) / (PDF)

13. Wohl MEB. Bronchiolitis. In: Chernick V, Boat TF (eds). Kendig's Disorders of the Respiratory Tract in Children. Philadelphia: Saunders, 2006: 423-32.

14. Carroll KN, Wu P, Gebretsadik T, et al. Season of infant bronchiolitis and estimates of subsequent risk and burden of early childhood asthma. J Allergy Clin Immunol 2009; 123: 964-6. (Abstract) / (Full Text) / (PDF)

15. Greenough A. The year in review. Paediatr Respir Rev 2009; 10: 2-5. (Abstract) / (PDF)

16. Nelson CT. Mycoplasma and chlamydia pneumonia in pediatrics. Semin Respir Infect 2002; 17: 10-4. (Abstract)

17. Koehoorn M, Karr CJ, Demers PA, Lencar C, Tamburic L, Brauer M. Descriptive epidemiological features of bronchiolitis in a population-based cohort. Pediatrics 2008; 122: 1196-203. (Abstract) / (Full Text) / (PDF)

18. Miyairi I, DeVincenzo JP. Human genetic factors and respiratory syncytial virus disease severity. Clin Microbiol Rev 2008; 21 : 686-703. (Abstract) / (Full Text) / (PDF)

19. Lee YM, Miyahara N, Takeda K, et al. IFN-g production during initial infection determines the outcome of reinfection with respiratory syncytial virus. Am J Respir Crit Care Med 2008; 177: 208-18. (Abstract) / (Full Text) / (PDF)

20. Behrendt CE, Decker MD, Burch DJ, Watson PH. International variation in the management of infants hospitalized with respiratory syncytialvirus. Eur J Pediatr 1998; 157: 215-20. (Abstract) / (PDF)

21. Simoes EAF. Respiratory syncytial virus infection. Lancet 1999; 354: 847-52. (Abstract) / (Full Text) / (PDF)

22. Lanari M, Silvestri M, Rossi G. Respiratory syncytial virus risk factors in late preterm infants. J Matern Fetal Neonatal Med 2009; 22: 102-7. (Abstract) / (Full Text) / (PDF)

23. Hacımustafaoğlu M. RSV infeksiyonları. Ankem Derg 2006; 20 : 240-7. (Abstract) 
24. Wohl MEB. Developmenttal physiology of the respiratory system. In: Chernick V, Boat TF (eds). Kendig's Disorders of the Respiratory Tract in Children. Philadelphia: Saunders, 2006: 23-8. 25. Thomsen SF, Stensballe LG, Skytthe A, Kyvik KO, Backer V, Bisgaard $\mathrm{H}$. Increased concordance of severe respiratory syncytial virüs infection in identical twins. Pediatrics 2008; 121: 493-6. (Abstract) / (Full Text) / (PDF)

26. Singh AM, Moore PE, Gern JE, Lemanske RF Jr, Hartert TV. Bronchiolitis to asthma: a review and call for studies of genevirus interactions in asthma causation. Am J Respir Crit Care Med 2007; 175: 108-19. (Abstract) / (Full Text) / (PDF)

27. Awomoyi AA, Rallabhandi P, Pollin TI, et al. Association of TLR4 polymorphisms with symptomatic respiratory syncytial virus infection in high-risk infants and young children. J Immunol 2007; 179: 3171-7. (Abstract) / (Full Text) / (PDF)

28. Amanatidou V, Sourvinos G, Apostolakis S, et al. RANTES promoter gene polymorphisms and susceptibility to severe respiratory syncytial virus-induced bronchiolitis. Pediatr Infect Dis J 2008; 27: 38-42. (Abstract)

29. Harris J, Werling D. Binding and entry of respiratory syncytial virus into host cells and initiation of the innate immune response. Cell Microbiol 2003; 5: 671-80. (Abstract) / (Full Text) / (PDF)

30. Alfhide C, Smyth RL. Innate immune response and bronchiolitis and preschool recurrent wheeze. Paediatr Respir Rev 2008; 9 : 251-62. (Abstract) / (Full Text) / (PDF)

31. Krishnan S, Halonen M, Welliver RC. Innate immune responses in respiratory syncytial virus infections. Viral Immunol 2004; 17: 220-33. (Abstract) / (PDF)

32. Legg JP, Hussain IR, Warner JA, Johnston SL, Warner JO. Type 1 and type 2 cytokine imbalance in acute respiratory syncytial virus bronchiolitis. Am J Respir Crit Care Med 2003; 168: 633-9. (Abstract) / (Full Text) / (PDF)

33. Turul T, Ersoy F. Dostla düşmanı ayıran bir doğal immünite bileşeni: Toll-like reseptörler (TLR). Hacettepe Tıp Dergisi 2004; 35: 114-8. (PDF)

34. Monick M, Yarovinsky TO, Power LS, et al. Respiratory syncytial virus up-regulates TLR4 and sensitizes airway epithelial cells to endotoxin. J Biol Chem 2003; 278: 53035-44. (Abstract) / (Full Text) / (PDF)

35. Haeberle HA, Takizawa R, Casola A, et al. Respiratory syncytial virus-induced activation of nuclear factor-kappa $B$ in he lung involves alveolar macrophages and Toll-like receptor 4 dependent pathways. J Infect Dis 2002; 186: 1199-206. (Abstract) / (PDF)

36. Tal G, Mandelberg A, Dalal I, et al. Association between common Toll Like receptor 4 mutations and severe respiratory syncytial virus disease. J Infect Dis 2004; 189: 2057-63. (Abstract) / (Full Text) / (PDF)

37. Tulic MK, Hurrelbrink RJ, Prêle CM, et al. TLR4 polymorphisms mediate impaired responses to respiratory syncytial virus and lipopolysaccharide. J Immunol 2007; 179: 132-40. (Abstract) (Full Text) / (PDF)

38. Ghildyal R, Hartley C, Varrasso A, et al. Surfactant protein A binds to the fusion glycoprotein of respiratory syncytial virus and neutralizes virion infectivity. J Infect Dis 1999; 180: 2009-13. (Abstract) / (Full Text) / (PDF)

39. Lahti M, Lofgren J, Marttila R, et al. Surfactant protein D polymorphism associated with severe respirator syncytial virus infection. Pediatr Res 2002; 51: 696-9. (Abstract) / (Full Text) / (PDF)

40. Sheeran $\mathrm{P}$, Jafri $\mathrm{H}$, Carubelli $\mathrm{C}$, et al. Elevated cytokine concentrations in the nasopharyngeal and tracheal secretions of children with respiratory syncytial virus. Pediatr Infect Dis $\mathrm{J}$ 1999; 18: 115-22. (Abstract)

41. Garofalo RP, Patti J, Hintz KA, Hill V, Ogra PL, Welliver RC. Macrophage inflammatory protein-1 alpha (not $\mathrm{T}$ helper 2 cytokine) is associated with severe forms of respiratory syncytial virus bronchiolitis. J Infect Dis 2001; 184: 393-9. (Abstract) / (Full Text) / (PDF)

42. Hull J, Rowlands K, Lockhart E, Moore C, Sharland M, Kwiatkowski $D$. Variants of the chemokine receptor CCR5 are associated with severe bronchiolitis caused by respiratory syncytial virus. J Infect Dis 2003; 188: 904-7. (Abstract) / (Full Text) / (PDF)
43. Puthothu B, Krueger M, Forster J, Heinze J, Weckmann M, Heinzmann A. Interleukin (IL)-18 polymorphism 133C/G is associated with severe respiratory syncytial virus infection. Pediatr Infect Dis J 2007; 26: 1094-8. (Abstract)

44. Hull J, Thomson A, Kwiatkowski D. Association of respiratory syncytial virus bronchiolitis with the interleukin 8 gene region in UK families. Thorax 2000; 55: 1023-7. (Abstract) / (Full Text) / (PDF)

45. McNamara PS, Flanagan BF, Hart CA, Smyth RL. Production of chemokines in the lungs of infants with severe RSV bronchiolitis. J Infect Dis 2005; 191: 1225-32. (Abstract) / (Full Text) / (PDF)

46. Ceprika AM, Gagro A, Bace A, et al. Expression of chemokines receptor CX3XC1 in infants with respiratory syncytial virus bronchiolitis. Pediatr Allergy Immunol 2008; 19: 148-56. (Abstract) / (Full Text) / (PDF)

47. Amanatidou V, Sourvinos G, Apostolakis S, Tsilimigaki A Spandidos DA. T280M variation of the CX3CR1 receptor gene is associated with increased risk for severe respiratory syncytial virus bronchiolitis. Pediatr Infect Dis J 2006; 25: 410-4. (Abstract)

48. van Schaik SM, Tristram DA, Nagpal IS, Hintz KM, Welliver RC 2nd, Welliver RC. Increased production of IFN-gamma and cysteinyl leukotrienes in virus-induced wheezing. J Allery of Clin Immunol 1999; 103: 630-6. (Abstract) / (Full Text) / (PDF)

49. Welliver RC 2nd, Hintz KH, Glori M, Welliver RC Sr. Zileuton reduces respiratory illness and lung inflammation, in respiratory syncytial virus infection in mice. J Infect Dis 2003; 187: 1773-9. (Abstract) / (Full Text) / (PDF)

50. Kao YJ, Piedra PA, Larsen GL, Colasurdo GN. Induction and regulation of nitric oxide synthase in airway epithelial cells by respiratory syncytial virus. Am J Respir Crit Care Med 2001; 163: 532-9. (Abstract) / (Full Text) / (PDF)

51. Kaltreider HB, Ichikawa S, Byrd PK, et al. Upregulation of neuropeptides and neuropeptide receptors in a murine model of immune inflammation in lung parenchyma. Am J Respir Cell Mol Biol 1997; 16: 133-44. (Abstract)

52. Rudd BD, Burstein E, Duckett CS, Li X, Lukacs NW. Differential role for TLR3 in respiratory syncytial virus induced chemokines expression. J Virol 2005; 796: 3350-7. (Abstract) / (Full Text) / (PDF)

53. Bartz H, Büning-Pfaue $F$, Türkel $O$, Schauer U. Respiratory syncytial virüs induces prostaglandin $\mathrm{E} 2, \mathrm{IL}-10$ and IL-11 generationin antigen presenting cells. Clin Exp Immunol 2002; 1293: 438-45. (Abstract) / (Full Text) / (PDF)

54. Trepicchio WL, Wang L, Bozza M, Dorner AJ. IL-11 regulates macrophage effector function through the inhibition of nuclear factor-kappa B. J Immuol 1997; 159: 5661-70. (Abstract) / (PDF)

55. Schlender J, Hornung V, Finke S, et al. Inhibition of Toll-like receptor 7 and 9 mediated alpha/beta interferon production in human plasmacytoid dendritic cells by respiratory syncytial virus and measles virus. J Virol 2005; 799: 5507-15.(Abstract) / (Full Text) / (PDF)

56. Schlender J, Bossert B, Bucholz U, et al. Bovine respiratory syncytial virüs non-structural proteins NS1 and NS2 cooperatively antagonise alpha/beta interferon induced antiviral response. J Virol 2000; 74: 8234-42. (Abstract) / (Full Text) / (PDF)

57. Olson MR, Varga SM. Pulmonary immunity and immunopathology: Lessons from respiratory syncytial virus. Expert Rev Vaccines 2008; 7: 1239-55. (Abstract) / (Full Text) / (PDF)

58. Soukup JM, Becker S. Role of monocytes and eosinophils in human respiratory syncytial virus infection in vitro. Clin Immuno 2003; 107: 178-85. (Abstract) / (PDF)

59. Bem RA, Bos AP, Bots $M$, et al. Activation of the granzyme pathway in children with severe respiratory syncytial virus infection. Pediatr Res 2008; 63: 650-5. (Abstract) / (Full Text) / (PDF)

60. Johnson TR, Hong S, Van Kaer L, Koezuka Y, Graham BS. NK $T$ cells contribute to expansion of CD8 T cells and amplification of antiviral immune responses to respiratory syncytial virus. $J$ Virol 2002; 76: 4294-303. (Abstract) / (Full Text) / (PDF)

61. Hussell T, Openshaw PJ. IL-12-activated NK cells reduce lung eosinophilia to the attachment protein of respiratory syncytial virus but do not enhance the severity of illness in CD8 T cellimmunodeficient conditions. J Immunol 2000; 165: 7109-15. (Abstract) / (Full Text) / (PDF)

62. Wang SZ, Xu H, Wraith A, et al. Neutrophils induce damage to respiratory epithelial cells infected with respiratory syncytial virus. Eur Respir J 1998; 12: 612-8. (Abstract) / (PDF) 